\title{
Scholarly Writings as a Source of Law: A Survey of the Use of Doctrine by the International Court of Justice
}

\author{
Michael Peil
}

\begin{abstract}
Article 38(1)(d) of the Statute of the International Court of Justice instructs the Court to apply, as a subsidiary means for the determination of rules of law, "the teachings of the most highly qualified publicists," namely, scholarly writings. Based upon a survey of more than 600 Judgments, Advisory Opinions and Orders, this paper describes the International Court of Justice's use of these sources and analyzes the individual scholars and writings which have been most useful to the Court. It also explores the meaning of a 'subsidiary source' and the contexts in which judges are most willing to utilize such sources.
\end{abstract}

\section{Keywords}

Sources of international law, Doctrine, Scholarly writings, International Court of Justice, Separate and dissenting opinions

\section{Introduction}

When deciding disputes between States, in addition to the three principal sources of international law, the International Court of Justice ('ICJ') is to draw upon "the teachings of the most highly-qualified publicists of the various

\footnotetext{
Associate Dean for International Programs and Lecturer in Law, Washington University School of Law. The author thanks Gleider Hernandez, Neil M. Richards, Melissa A. Waters, Russell Dalferes, and the participants in the 2012 Cambridge Journal of International and Comparative Law annual conference for their helpful comments on earlier drafts. He also thanks Shannon P. Dobson, J.D. '2011, LL.M. '2012, for her excellent translation work on decisions and other materials available only in French. The author accepts exclusive responsibility for the content herein.
} 
nations". However, the Statute is silent on the meaning of "most highly qualified", and the travaux préparatoires offer little guidance on this point.

Unlike the other three sources of law, the Court may use the teachings of publicists only "as subsidiary means for the determination of rules of law". The drafters of the Statute disagreed as to the proper role for these teachings, referred to as 'doctrine', and the meaning of "subsidiary" in this context is unclear.

The Court has only rarely invoked doctrine in its Judgments, Advisory Opinions, and Orders. This has not stopped counsel from routinely calling the teachings of publicists to the Court's attention in written and oral arguments, and individual judges freely cite la doctrine in their individual opinions. This latter practice led Sir Humphrey Waldock, later a Judge of the ICJ, to observe, "[t]he way in which individual judges quite often make use of them in their separate opinions indicates that they have played a part in the internal deliberations of the Court and in shaping opinion.'1]

In Section 2, the paper analyzes the language of the Statute and its negotiating history for guidance as to the meaning of both concepts. In Section 3 , I describe some of the 'conventional wisdom' derived from prior scholarly analysis of the Court's use of highly-qualified publicists. In Section 4, I set out the methodology of my survey of the Court's writings, including a discussion of how I determined when the Court is "apply[ing] ... the teachings of the most highly qualified publicists". In Section 5, I summarize the findings of my survey. I conclude by setting out plans for further study.

\section{The language of the Statute}

According to Article 38(1) of its Statute, in rendering its judgments, the International Court of Justice relies upon three principal sources of law: ${ }^{2}$

(a) international conventions, whether general or particular, establishing rules expressly recognized by the contesting states;

1 H. Waldock, (1962/II) 106 Hague Recueil 1, at 96. More recently, Alain Pellet adds that "the quite abundant references to the opinions of writers in the opinions of the individual judges ... suggests that these views have probably been discussed during the deliberation." A. Pellet, 'Article 38', in A. Zimmerman, et al., The Statute of the International Court of Justice: A Commentary (Oxford, 2006), at 791-2.

2 G. Schwarzenberger, International Law as Applied by International Courts and Tribunals (Stevens and Sons Ltd., 1957), Vol. 1, at 36. 
(b) international custom, as evidence of a general practice accepted as law; [and]

(c) the general principles of law recognized by civilized nations $\mathrm{3}^{3}$

In addition, Article 38(1)(d) provides in very particular language for reliance upon a fourth source of law:

subject to the provisions of Article 59, judicial decisions and the teachings of the most highly-qualified publicists of the various nations, as subsidiary means for the determination of rules of law ${ }^{4}$

Given the lack of clarity in these terms, reference to the travaux préparatoires of Article 38, as well as subsequent interpretation by experts in the procedure and practice of the Court, is in order.

\subsection{The travaux préparatoires of Article 38(1)}

The sources of law enumerated in Article 38(1) are drawn materially verbatim from the Statute of the Permanent Court of International Justice ('PCIJ'). It is therefore appropriate to review briefly the discussions of the Advisory Committee of Jurists, the multi-national committee of experts tasked by the League of Nations to draft the PCIJ Statute.

Doctrine was not included in the original draft of the rules of law to be applied by Court. The President of the Committee, Baron Descamps.5 prepared a draft which enumerated only conventions, custom, the "legal conscience of civilised nations", and international jurisprudence. In his remarks the following day, however, Descamps indicated a desire to add "objective justice" to the sources of law, reasoning that "it is absolutely impossible and supremely odious to say to the judge that, although in a given case a perfectly just solution is possible: 'You must take a course amounting to a refusal of justice' merely because no definite convention or custom appeared. 6 He suggested that, in determining the rules of objective justice, the Court be permitted to use, inter alia, "the concurrent teaching of the authors whose opinions have authority" 7

1945 Statute of the International Court of Justice, 33 UNTS 993, Art. 38(1).

4 Ibid., Art. 38(1)(d).

5 Procés-Verbaux of the Advisory Committee of Jurists (1920), at 306.

6 Ibid., at 323.

7 Ibid. Descamps invoked Chancellor Kent: "when the greater part of jurisconsults agree upon a certain rule-the presumption in favor of that rule becomes so strong, that only a person who makes a mock of justice would gainsay it." Ibid. 
It was clear at this time that Baron Descamps intended for doctrine to be a 'tie-breaker', to avoid a non liquet in the event that principal rules of law were non-existent or inconclusive. He explained:

If neither [treaty] law nor custom existed, could the judge pronounce a non liquet? The President was convinced that he could not; the judge must then apply general principles of law. But he must be saved from the temptation of applying these principles as he pleased. For that reason he urged that the judge render decisions in keeping with the dictates of the legal conscience of civilised peoples and for this same purpose make use of the doctrines of publicists carrying authority $\left.\right|^{8}$

Mr. Root and Lord Phillimore responded by submitting an alternative draft, which introduced the four-element structure reflected in present-day Article 38(1), albeit with an explicit hierarchy of sources. The Root-Phillimore proposal ranked doctrine fourth in this hierarchy, and described it as "the opinions of writers as a means for the application and development of law"?

Baron Descamps responded to the Root-Phillimore draft by emphasizing that "the judge must use the ... coinciding doctrines of jurists, as auxiliary and supplementary means, only" ${ }^{10}$ Mr. Ricci-Busatti expressed skepticism that "it would be possible to find coinciding doctrine concerning points in relation to which no generally recognised rules existed" 1 More fundamentally, he "denied most emphatically that the opinions of authors could be considered as a source of law to be applied by the Court" 12 Lord Phillimore, the author of the draft, replied that doctrine was "universally recognised as a source of international law", but that "only the opinions of widely recognised authors" would be considered 13

Mr. Ricci-Busatti "doubted whether States would really accept rules which would be the result of the doctrine rather than of their own will, or of their usages" ${ }^{14}$ and asked in fine whether Lord Phillimore's own government would accept a judgment based solely upon the doctrine of legal writers; Lord

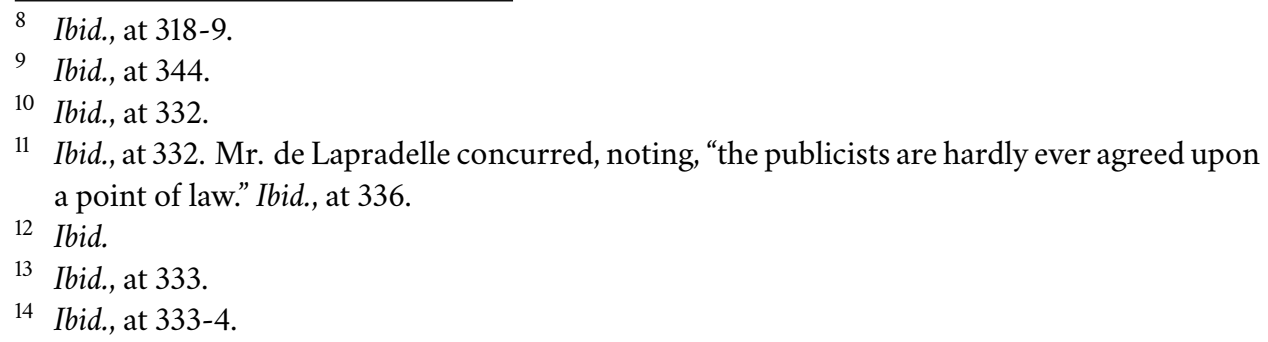


Phillimore "thought that this was possible" 15 Mr. Ricci-Busatti had in fact submitted a competing draft, which removed doctrine as a source of law, but instructed the Court to "take into consideration ... the opinions of the best qualified writers of the various countries, as means for the application and development of law"16

Mr. de Lapradelle opposed including doctrine in the draft, but insisted that if it were included, it be "limited to coinciding doctrines of qualified authors in the countries concerned in the case $[17$ He also proposed that the sources of doctrine be "arranged according to their importance" with, for example, the Institut de droit international at the top of the list ${ }^{18}$ None of his proposals were taken up by the Committee.

In the end, the issue was not resolved-with Baron Descamps and Mr. Ricci-Busatti repeatedly emphasizing "the auxiliary character of [doctrine] as elements of interpretation" ${ }^{19}$ and later emphasizing "doctrine and jurisprudence no doubt do not create law; but they assist in determining rules which exist" 20 and Lord Phillimore insisting that "custom is formed by the usage followed in various public and formal documents, and from the works of writers who agree upon a certain point" ${ }^{21}$

The Committee agreed upon compromise language for the second reading, "the doctrines of the best qualified writers of the various nations as a means for the application and development of law" 22 The drafting committee modified this to "rules of law derived from ... the teachings of the most highly qualified publicists of the various nations" 23 In the second reading, Baron Descamps proposed adding "as subsidiary means for the determination of rules of law", and this amendment was adopted along with the Article as a whole without recorded discussion 24

In conclusion, the Committee settled on intentionally ambiguous language ("as subsidiary means" and "the teachings of the most highly qualified publicists") without resolving the underlying disagreements between Root and Phillimore, on the one hand, and Descamps and Ricci-Busatti, on the other.

15 Ibid., at 333.

16 Ibid., at 351.

17 Ibid., at 336 (emphasis added).

18 Ibid.

19 Ibid., at 334.

${ }^{20}$ Ibid., at 336.

21 Ibid.

22 Ibid.

23 Ibid., at 567.

24 Ibid., at 584. 


\subsection{Subsequent treatment by scholars}

Writing in his private capacity while serving as a judge at the PCIJ, Manley O. Hudson described the ambiguity surrounding "subsidiary means" aptly:

What is meant by subsidiary is not clear. It may be thought to mean that these sources are to be subordinated to others mentioned in the article, i.e. to be regarded only when sufficient guidance cannot be found in international conventions, international custom and general principles of law; the French term auxiliaire seems, however, to indicate that confirmation of rules found to exist may be sought by referring to jurisprudence and doctrine 25

Hudson concluded, however, "[j] udicial decisions and the teachings of publicists are not rules to be applied, but sources to be resorted to for finding applicable rules.'26

Subsequent scholarly treatment has followed Hudson's reasoning. Scholars themselves have treated Article 38(1)(d) as not only subsidiary, but also qualitatively different than the primary sources of subheads (a), (b) and (c).

In his Hague Academy lectures upon stepping down from the Court, Judge Manfred Lachs summed up the spirit of the scholars when describing the status of even the best-known publicists as sources of law: "[n] evertheless, of none, not even of my heroes, could I say: 'this man made law.' For teachers are not legislators, nor lawmakers in international relations. The 'teachings' of the most highly qualified publicists of various nations are only 'subsidiary means for the determination of rules of law."27

Shabtai Rosenne reasoned from a voluntarist notion of public international law, observing that "[d]octrine is not positive international law as previously described, nor does it stand on the same basis as international judicial decisions since it is not the product of direct or indirect action of States. For that reason alone, the role of doctrine is truly 'subsidiary." 28 He concluded that doctrine was "an entirely different aspect, namely means for the determination of rules of law, that is rules falling into any one of heads (a), (b) and (c)". He described

25 M. Hudson, The Permanent Court of International Justice 1920-1942 (MacMillan, 1943), at 612.

26 Ibid.

27 M. Lachs, (1976/III) 151 Hague Recueil 161, at 169.

28 S. Rosenne, Practice and Methods of International Law (Oceana, 1984), at 119. 
Article 38(1)(d) sources as merely "the storehouse from which the rules ... can be extracted"29

This followed the earlier conclusion of Schwarzenberger-who described subhead (d) as simply enumerating "some of the means for the determination of alleged rules of international law' 30 -and Waldock-who observed in 1962 that it was "universally agreed" that jurisprudence and doctrine were merely "evidentiary sources which may assist in satisfying the Court as to the existence of a conventional or customary rule or of a general principle of law" 31

While the scholars are in universal agreement as to the meaning of "subsidiary", they offer little guidance as to the meaning of "most highly qualified". In addition to the quote from Schwarzenberger in the introduction, Rosenne observes, " $t]$ here is, of course, no way of establishing who is a 'most highly qualified publicist' of any nation. This is a matter for the skill, knowledge and appreciation of the individual legal advisor. ${ }^{32}$

\section{Prior scholarly analysis of the Court's use of doctrine}

Having established its proper place in the sources hierarchy, scholarly discussion concerning doctrine has focused on two issues: the kinds of writings that constitute "teachings" and the paucity of doctrine cited by the Court in its Judgments, Advisory Opinions and Orders. In my review of the practice of the judges-principally in individual and joint opinions-I seek to examine the conventional wisdom concerning doctrine laid out in this section.

\subsection{What constitutes a "teaching"?}

The question of who is a "publicist" is closely related to that of what constitutes a "teaching". After all, "[w] hile one cannot possibly dissociate the 'teachings' expressed in writings or viva voce from 'the teacher', there are those other activities in which the teacher has participated throughout the centuries:. ${ }^{33}$ The

\footnotetext{
29 S. Rosenne, The Law and Practice of the International Court, 1920-2005 (Brill, 2006), Vol. III, at 1551 .

30 Schwarzenberger, supra note 2, at 26.

31 Waldock, supra note 1 , at 88.

32 Rosenne, supra note 28 , at 119.

33 Lachs, supra note 27, at 218.
} 
modern scholar wears at least two hats: that of faithful chronicler of the state of the law, and that of passionate advocate for development of the law 34

Judge Lachs quoted with approval Justice Gray's remarks in The Paquete Habana ${ }^{35}$ to the effect that "[s] uch works are resorted to by judicial tribunals, not for the speculations of their authors concerning what the law ought to be but for trustworthy evidence of what the law really was. ${ }^{36}$

The distinction is important, as the Court's "function is to decide in accordance with international law" 37 that is, consistent with lex lata. The distinction has not always been respected: Lauterpacht noted "the prolific and occasionally indiscriminate citation of authors in the written and oral pleadings of the parties $\sqrt{38}$, while Schwarzenberger castigated the scholars themselves, noting, "[n]othing has brought the doctrine of international law into greater disrepute than proneness of individual representatives to present desiderata de lege ferenda in the guise of propositions de lege lata: ${ }^{39}$

In light of this concern, Schwarzenberger demanded scholars "try [their] hardest not to blur the border lines between lex lata and lex ferenda" ${ }^{40}$ One purpose of this study is to determine whether publicists have succeeded and whether ICJ decisions reflect a corresponding care for those border lines.

\subsection{Why has the Court not cited doctrine?}

The Court has cited publicists in only 22 of its 139 Judgments and Advisory Opinions ${ }^{41}$ Writing in 1958, Sir Hersch Lauterpacht noted that this practice was at odds with the plain language of the Court's Statute:

Article 38 is explicit on that subject; it is mandatory in its reference to the "teachings of publicists" as a subsidiary source of the law

\footnotetext{
34 This is nothing new. Brownlie notes that "Gidel has had some formative influence on the law of the sea." I. Brownlie, Principles of Public International Law (Oxford University Press, 2003), at 23. Clive Parry notes the singular contributions that Borchard's work made to the development of diplomatic protection. C. Parry, The Sources and Evidences of International Law (Oceana, 1965), at 107.

35 The Paquete Habana, 1899, 175 U.S. 677.

${ }^{36}$ Lachs, supra note 27, at 212 (citation omitted).

37 ICJ Statute, supra note 3, Art. 38(1).

${ }^{38}$ H. Lauterpacht, The Development of International Law by the International Court (Stevens \& Sons, 1958), at 25.

39 G. Schwarzenberger, 'The Province of the Doctrine of International Law', (1956) 9 Current Legal Problems 235, at 244.

40 Ibid., at 259.

41 For my methodology in determining these numbers, see infra Section 4.
} 
to be applied by the Court. A study of the deliberations of the Committee of Jurists who drafted the Statute of the Court does not bear out any suggestion that the authority thus conferred upon the Court ought to remain nominal ${ }^{42}$

The contrast between the Statutory mandate and practice was-and remainsstriking. At the time of Lauterpacht's observation, the Court had delivered 28 Judgments and Advisory Opinions, and had cited publicists on only two occasions: in the Anglo-Norwegian Fisheries case ${ }^{43}$ and in Nottebohm ${ }^{44}$

Writers have commonly posited five causes for the reticence of the Court to refer explicitly to doctrine.

The first theory derives from the voluntarist perspective. In this spirit, Waldock noted sympathetically, "the Court prefers, if possible, to base itself on evidence more obviously emanating from States or from tribunals invested by States with law-determining authority:. ${ }^{45}$ This reason is unsatisfying, as it reduces the act of citation to a mere formality. After all, the parties' oral and written pleadings are publicly available, and "perusal of the pleadings ... will quickly show the authorities brought to the attention of the court or tribunal and enable the discerning reader to see for himself what teachings of what publicists were adopted by the Court" ${ }^{46}$

The second cause presented suggests that jurisprudence is displacing doctrine as the preferred subsidiary source. Namely, "with the growth of international judicial activity ... it is natural that reliance on the authority of writers as evidence of international law should tend to diminish" 47 This suggestion fails for two reasons. First, while it may be (in the authors' minds) 'natural' to privilege jurisprudence over doctrine, such a preference is nowhere authorized or implied in the Statute, which makes no distinction between the two in subhead (d). Second and more importantly, it presupposes that at some

42 Lauterpacht, supra note 38, at 24-5.

${ }^{43}$ Fisheries (United Kingdom v Norway), Merits, Judgment, ICJ Reports 1951, p. 116, at 129 (referring to "the experts of the Second Sub-Committee of the Second Committee" of the 1930 Hague Codification Conference).

${ }^{44}$ Nottebohm (Liechtenstein v Guatemala), Second Phase, Judgment, ICJ Reports 1955, p. 4, at 22 (noting generally that " $\mathrm{t}$ ]he same tendency prevails in the writings of publicists and in practice").

45 Waldock, supra note 1, at 96.

${ }^{46}$ Rosenne, supra note 28 , at 119.

47 R. Jennings and A. Watts (eds), Oppenheim's International Law (Longman, 1992), at 42. See also Parry, supra note 34, at 104 ("[I]t is also no doubt true that, as the body of judicial decisions increases, the authority of the commentator is diminished"). 
early point in the Court's history, it did in fact rely upon doctrine; as noted above, this is simply not the case.

The third cause may be termed 'technological'. If the role of the publicist is simply to summarise State practice or evidences of general principles, that function is progressively supplanted as publishers (first print, then electronic) make access to primary sources more readily available. Writing well before the advent of the Internet, Lauterpacht observed, "[t]here is no doubt that the availability of official records of the practice of states and of collections of treaties has substantially reduced the necessity for recourse to writings of publicists as evidence of custom. ${ }^{48}$ This justification ignores, however, the true value of the learned publicist, namely, "to make a synthesis from the decisions, sometimes to detect a thread of principle running through them, and often to indicate the true line of development and the danger of getting onto the wrong track" 49

The fourth concerns the process of the Court's deliberations. As demonstrated by the wide divergence of opinion in Separate Opinions, individual judges frequently agree as to the result but disagree fundamentally as to the legal basis for that result. For this reason, "the practice of including citations of individual publicists does not sit well with the concept of a collective pronouncement of what the law is" ${ }^{50}$ Taken at face value, however, this rationale suggests that any disagreement among the majority judges as to the source of a rule-for example, in the situation where an obligation might derive from conventional or customary law, or from one of two conventions-results in the source being excised from the decision. This ignores the role that Separate Opinions play in the development of the law. As Rosenne observed,

It has for some time been commonly felt among competent observers of the Court that individual opinions which, so to speak, underpin the anonymous decisions of the Court, thanks to their greater freedom of expression and emphasis on underlying principles which the anonymous author of the majority view cannot always articulate fully, or which, in another direction, by

\footnotetext{
${ }_{48}$ Lauterpacht, supra note 38, at 24.

49 A. McNair, The Development of International Justice (NYU Press, 1954), at 17. See also Jennings \& Watts, supra note 47, at 42 (noting "inasmuch as a source of law is conceived as a factor influencing the judge in rendering his decision, the work of writers may continue to play a part in proportion to its intrinsic scientific value, its impartiality and its determination to scrutinise critically the practice of states by reference to legal principle." (citations omitted).)

50 Rosenne, supra note 28, at 120.
} 
indicating other legal principles which can govern the particular circumstances, may correct any misleading impression which the majority opinion might convey, or which, by flatly contradicting it, are seen by enlightened legal opinion to be expressive of better law, have a value of their own not so much for the development of the law as for the proper functioning of the Court ${ }^{51}$

Finally, authors have noted that the reticence may simply be a matter of etiquette. Rosenne delicately refers to the "the inherent and embarrassing difficulty of saying who is a "most highly qualified publicist" 52 and, by negative implication, who-among the countless others writing on the same topic-is less qualified. Pellet notes, less tactfully, "[i]nternational law is a 'small world' not exempt from jealousy and envy and the Court is certainly well-advised not to distribute good or bad marks.'53

However, the frequency with which individual and joint opinions name individual authors suggests that judges do not feel particularly embarrassed, though the point is taken that those judges, collectively, might wish to avoid giving the imprimatur of the Court to an individual scholar, paving the way for the creation of a new Digest. $\left[{ }^{54}\right.$

Furthermore, the decisions of the Court have frequently made use of both the deliberations and work-product of the UN International Law Commission. For the former, Alain Pellet cites the example of the 1969 North Sea Continental Shelf Judgment, "where the Court concluded from the work of the Commission that the equidistance rule was not envisaged by it as a customary rule" 5 and for the latter, he notes the 1997 Gabčikovo-Nagymaros judgment, "where the Court quoted not less than seven times from the Articles on State Responsibility

51 S. Rosenne, 'Sir Hersch Lauterpacht's Concept of the Task of the International Judge', (1961) 55 AJIL 825, at 861, cited in M. Shahabuddeen, Precedent in the World Court (Cambridge University Press, 1996), at 195.

52 Rosenne, supra note 28 , at 119.

53 Pellet, supra note 1 , at 792.

54 See W. Buckland and A. McNair, Roman Law and Common Law: A Comparison in Outline (Cambridge University Press, 1936), at 13: "It is true that the principal source of law in Justinian's time, the Digest, is made up of juristic writings and these writings are declared to be selected from the writings of jurists who had had some sort of authority. But the authority of the texts in the Digest is not due to their having been written by the jurist, but to their having been incorporated in the Digest and made law by enactment."

55 North Sea Continental Shelf (Germany v Denmark; Germany v Netherlands), Merits, Judgment, ICJ Reports 1969, p. 3, at 33, para. 49, cited in A. Pellet, supra note 1, at 757-8, para. 49. 
adopted after first reading by the Commission" 56

Rosenne convincingly justifies the "special place" reserved for the ILC, noting that "it is not composed of the representatives of States but of experts sitting in their individual capacity" and that it was "created by States in the General Assembly to enable the General Assembly to carry out its obligation under Article 13(1)(a) of the Charter, that is for the very purpose of the progressive development and codification of international law" $[57$ This mandate in particular distinguishes the ILC from other, freelance publicists.

\section{Methodology of this survey}

The process of culling bona fide teachings from over 14,000 pages of opinions required several stages of review. The following process is not intended to be scientific, but was rather intended as a first pass, to enable me to make preliminary observations and prepare a methodology for a later, more empirically rigorous study.

\subsection{Documentary scope}

For this survey, I read the English-language ${ }^{58}$ versions of 112 Judgments, 27 Advisory Opinions and 489 Orders of the ICJ issued as of 1 May 2012, as well as the approximately more than 1300 Declarations, Separate Opinions, and Dissenting Opinions appended thereto. I excluded from my survey most of the unanimous or Presidential one-page Orders concerning, inter alia, fixing or extension of time-limits or composition of the Court, unless they were contentious-as indicated by the presence of Declarations, Separate Opinions, or Dissenting Opinions.

I used the PDF-formatted documents available from the ICJ's official website ${ }^{59}$ and read them cover-to-cover, manually noting any reference to a

56 Gabčkovo-Nagymaros (Hungary v Slovakia), Merits, Judgment, ICJ Reports 1997, p. 7, at 38-42 (paras. 47, 50-4), 46 (para. 58), cited in A. Pellet, supra note 1, at 757-8 (para. 50).

57 Rosenne, supra note 29, at 1560.

58 Owing to my linguistic deficiency, my research assistant, Ms. Shannon Dobson (JD '11, LLM '12) read the documents which were, at the time of this study, unavailable in English. Those documents are included in my numbers.

59 Official Website of the International Court of Justice, <http://www.icj-cij.org/> [last accessed 2 April 2012]. A consolidated, chronological list of all Judgments, Advisory Opinions, and Orders of the Court is available online at $<\mathrm{http} / / /$ www.icj-cij.org/docket/in dex.php?p1 $=3 \&$ p2 $=5>$ [last accessed 3 February 2013]. I checked this list against the lists 
scholar, writing, or other potential 'teaching' for later analysis according to my methods described below in subsection 4.2. At this stage, my standards for a 'teaching' were deliberately over-inclusive, in order to gauge the breadth of the Court's use of publicist-like authorities, including authors (legal or otherwise) and expert commissions.

For each putative teaching, I created an 'entry' which included the PDF file number, the case, the authoring judge(s), the page number on which the citation occurred, the identity of the source, and the cited material in the context of the opinion. This process led to approximately 1,400 pages of material.

\subsection{Culling the entries}

In the second stage, I worked through the entries and began removing those which did not constitute a legal 'teaching'. An example of a characteristic application of a publicist's teaching can be found in Judge Dillard's Separate Opinion in the 1974 Fisheries Jurisdiction judgment, where he cited McDougal and Burke's The Public Order of the Oceans ${ }^{60}$ stating:
After a characteristically thorough survey, McDougal and Burke conclude that "Practically all international agreements since the beginning of...conservation effort in $1911 . .$. witness the general understanding that the participation of all States substantially concerned with a fishery is necessary for effective action"

In this case, we have authors and a reference to a specific teaching. The authors' methodology (if not their qualifications) are established in the citation, and the Court states the purpose for which it is relying upon their teachings. Most references do not meet these exacting criteria and, indeed, there are considerable grounds for disagreement as to the 'teaching' nature of many references. It is important, therefore, that I set out my own criteria for including or excluding a source. These criteria will be reevaluated in the next phase of this study, but chief among them are, inter alia, as follows:

Agreeing with Brownlie's conclusion in this respect, I included "[s]ources analogous to the writings of publicists, and at least as authoritative, are the draft

of Orders, Judgments and Opinions delivered in each case or proceeding-a list of the cases and proceedings is available at $<\mathrm{http}: / / \mathrm{www}$.icj-cij.org/docket/index.php?p1=3\&p2=2>[last accessed 3 February 2013].

${ }^{60}$ M. McDougal and W. Burke, The Public Order of the Oceans (New Haven Press, 1962).

${ }^{61}$ Fisheries Jurisdiction (United Kingdom v Iceland), Merits, Judgment, ICJ Reports 1974, p. 3, at 68 , note 12 (Judge Dillard, Separate Opinion). 
articles produced by the International Law Commission, reports and secretariat memoranda prepared for the Commission, Harvard Research drafts, the bases of discussion of the Hague Codification Conference of 1930, and the reports and resolutions of the Institute of International Law and other expert bodies" 62

I exclude references to prior Judgments of the Court. This is for two reasons. First, these judgments could textually be placed in the other category of Article 38(1)(d), namely, "judicial decisions". Second, much has already been written on the use of judicial precedents by the ICJ ${ }^{63}$ and it is not the purpose of this paper to contribute to that discussion.

More controversially, I exclude references to prior individual opinions of the Court itself. Although these sources are rightly considered the teachings of publicists ${ }^{64}$ the number of citations is enormous compared to those to other publicists, and this matter is properly the subject of a separate study.

I excluded references to counsel's oral or written arguments, on the grounds that these references were intended to illustrate a party's position, not to establish authority.

I excluded entries in which scholars merely report a single case or arbitral decision, for example, those included at pp. 44-6 of Judge Alfaro's Separate Opinion at the Merits stage of the Temple of Preah Vihear case ${ }^{65}$

I excluded references to the writings of leading scholars to establish facts, as Article 38(1) concerns sources of law. Therefore, for example, when Judge De Castro in Western Sahara extensively cites several historians and legal scholars to establish the factual ties between the Western Sahara region and the Kingdom of Morocco, I exclude all of these sources ${ }^{66}$ Such citations are frequent, especially

${ }^{62}$ I. Brownlie, supra note 34, at 24.

63 See, e.g. Gilbert Guillaume, 'The Use of Precedent by International Judges and Arbitrators', (2011) 2 J. of Int'l Dispute Settlement 5, at 7-12.

64 See M. Shahabuddeen, supra note 51, at 199-200 (noting the opinions of Korowicz and Judge Ammoun that individual opinions are the writings of "particularly well-qualified jurists ... under the head of 'the teaching of publicists"' (citations omitted)). See also Land, Island and Maritime Frontier Dispute (El Salvador v Honduras), Application by Nicaragua for Permission to Intervene, Judgment, ICJ Reports 1990, p. 3, at 45 (Judge Shahabuddeen, Dissenting Opinion), in which Judge Shahabuddeen notes that the importance of judicial independence "has been rightly stressed in the literature" (emphasis added), citing only to separate opinions of Judges Zoricic and Winiarski.

65 Temple of Preah Vihear (Cambodia v Thailand), Merits, Judgment, ICJ Reports 1962, p. 6, at 44-6 (Judge Alfaro, Separate Opinion). For example, Judge Alfaro cites to an article by Bowett for nothing more than a one-paragraph précis of the Serbian Loans case. Ibid., at 44.

66 Western Sahara, Advisory Opinion, ICJ Reports 1975, p. 12, at 147-164 (Judge De Castro, Separate Opinion). 
in the Court's numerous demarcation opinions, in which establishing historical fact is of the essence.

I excluded references to the travaux préparatoires of conventions negotiated by representatives of States. The travaux are, of course, useful to the judges for the purpose of establishing the negotiating history of a treaty in force between the States parties ${ }^{67}$ However, even when the speaker is a well-regarded legal scholar, such statements are the political and negotiating position of a State, not an authoritative statement of what the law is 68

I excluded references to extra-legal authorities for purposes of, for example, principles of logic ${ }^{69}$

I excluded references in the form of appeals to policy, even where the citation is to an otherwise law-related source 70

I exclude citations to dictionaries-even legal dictionaries-that merely recite a definition 17 In contrast, citations to self-described 'dictionaries' - for

67 Article 32 of the Vienna Convention on the Law of Treaties permits recourse to "supplementary means of interpretation, including the preparatory work of the treaty and the circumstances of its conclusion" in order to confirm the prima facie interpretation of the meaning of a treaty provision, or where such prima facie interpretation "leaves the meaning ambiguous or obscure; or leads to a result which is manifestly absurd or unreasonable." 1969 Vienna Convention on the Law of Treaties, 1155 UNTS 331, Art. 32.

68 See, e.g., Nuclear Tests (Australia v France), Merits, Judgment, ICJ Reports 1974, p. 253, at 329, para. 36 (Judges Onyeama, Dillard, Jiménez de Aréchaga and Waldock, Dissenting Opinion), which refers to the "records of the League of Nations Assembly", and particularly the comments of the Belgian delegate, concerning the relationship between the League and the General Act.

69 See, e.g., Corfu Channel (United Kingdom v Albania), Merits, Judgment, ICJ Reports 1949, p. 4, at 81, para. 5 (Judge Azevedo, Dissenting Opinion). "We have thus eliminated all other possibilities than the explanation that a minefield was laid after the end of enemy action: we thus succeed, by a process of elimination, in isolating a single antecedent, which is thus transformed into a veritable cause, according to the classical rules of John Stuart Mill." See also Appeal Relating to the Jurisdiction of the ICAO Council (India v Pakistan), Merits, Judgment, ICJ Reports 1972, p. 46, at 96, note 1 (Judge Dillard, Dissenting Opinion) (explaining away apparently conflicting arguments by India counsel by reference to the Principia Mathematica and two other basic logic textbooks).

70 Corfu Channel case, supra note 69, at 118 (Judge Ecer, Dissenting Opinion) (citing D. Sandifer, Evidence before International Tribunals (Foundation Press, 1939), at 3, stating "[t]he vital interests of States, directly concerning the welfare of thousands of people, may be adversely affected by a decision based upon a misconception of facts.").

71 See, e.g., Maritime Delimitation in the Area between Greenland and Jan Mayen (Denmark $v$ Norway), Merits, Judgment, ICJ Reports 1993, p. 38, at 227, paras. 54 and 55 (Judge Weeramantry, Separate Opinion), in which Judge Weeramantry references Black's Law Dictionary - as well as, for historical perspective, Berger's Encyclopaedic Dictionary of Roman Law and Justinian's Digest-all for a definition of "equity". 
example, Basdevant's Dictionnaire de la terminologie du droit international $]_{2}^{72}$ which contain legal support or argumentation for their entries, were included.

By the end of this process, I reduced the number of entries to 3,857 and these are the basis for my observations, infra. This remaining dataset is likely still over-inclusive, as many of the facially law-oriented references may not have been intended by the judge to demonstrate a rule of law.

\section{Observations}

As a result of the survey, I was able to make several preliminary observations. The following observations are largely quantitative, and are intended as a reference for further study.

\subsection{The Court is, in fact, quite reticent to cite publicists}

As mentioned above, the Court has explicitly cited publicists in only 22 of its 139 Judgments and Advisory Opinions ${ }^{73}$

72 J. Basdevant (ed), Dictionnaire de la terminologie du droit international (Sirey, 1960), cited, e.g., in South West Africa (Ethiopia v South Africa; Liberia v South Africa), Second Phase, Judgment, ICJ Reports 1966, p. 6, at 54 (Judge Spender, Declaration) for the definition of an individual concurring opinion.

73 In addition to the references in the Fisheries case and in Nottebohm mentioned above, these include: Legal Consequences for States of the Continued Presence of South Africa in Namibia (South West Africa) notwithstanding Security Council Resolution 276 (1970), Advisory Opinion, ICJ Reports 1971, p. 16, at 48, para. 100 (reference to Smuts's 'The League of Nations: A Practical Suggestion'); North Sea Continental Shelf case, supra note 55, at 33, 34 and 51, paras. 48, 50 and 95 (three citations to the ILC); Military and Paramilitary Activities in and against Nicaragua (Nicaragua v United States), Merits, Judgment, ICJ Reports 1986, p. 14, at 100 and 124-5, para. 190 and 242 (one cite apiece to the ILC and the ICRC); Land, Island and Maritime Frontier Dispute (El Salvador v Honduras; Nicaragua intervening), Merits, Judgment, ICJ Reports 1992, p. 351, at 567, 592 and 593, paras. 350, 392 and 394 (references to Sir Cecil Hurst, Gidel, Oppenheim's International Law, and Vallejo); Gabčikovo-Nagymaros case, supra note 56, at 38-42 and 46, paras. 47, 50-4 and 58; Land and Maritime Boundary between Cameroon and Nigeria (Cameroon v Nigeria), Preliminary Objections, Judgment, ICJ Reports 1998, p. 275, at 294, para. 31 (two references to the ILC); Differences Relating to Immunity from Legal Process of a Special Rapporteur of the Commission on Human Rights, Advisory Opinion, ICJ Reports 1999, p. 62, at 87, para. 62 (ILC); Kasikili/Sedudu Island (Botswana v Namibia), Merits, Judgment, ICJ Reports 1999, p. 1045, at 1062, 1075-6, paras. 25 and 49 (two references to the ILC and one to the Institut de droit international); Maritime Delimitation and Territorial Questions between Qatar and Bahrain (Qatar v Bahrain), Merits, Judgment, ICJ Reports 2001, p. 40, at 76-7, 


\subsection{The ILC continues to enjoy a privileged position}

The International Law Commission is far and away the most common source relied upon by the judges. Of the 3,857 references in the survey, 384 (approximately ten percent) are to the ILC. The ILC is cited in 134 different opinions. Furthermore, of the 59 citations to publicists contained in the Judgments and Advisory Opinions of the Court, 45 are to the ILC.

The Court-and individual judges-have made use of the drafts and finished product of the Commission, as well as of the discussions reflected in the ILC Yearbook, and to conclusions reported by its Rapporteurs.

This is as large as the next four sources combined. It also compares favourably to the other learned societies: the Institut de droit international was referenced 85 times in 44 different opinions; and the International Law Association and the ICRC were referenced 18 times apiece; and the American Law Institute was referenced 16 times.

para. 113 (reference to the ILC and its Special Rapporteur, Georges Scelle); Land and Maritime Boundary between Cameroon and Nigeria (Cameroon v Nigeria; Equatorial Guinea intervening), Merits, Judgment, ICJ Reports 2002, p. 303, at 430, para. 265 (ILC); Legal Consequences of the Construction of a Wall in the Occupied Palestinian Territory, Advisory Opinion, ICJ Reports 2004, p. 136, at 175, 176 and 195, paras. 95, 97 and 140 (two references to the ICRC and one to the ILC); Armed Activities on the Territory of the Congo (Democratic Republic of the Congo $v$ Uganda), Merits, Judgment, ICJ Reports 2005, p. 168, at 226, para. 160 (ILC); Application of the Convention on the Prevention and Punishment of the Crime of Genocide (Bosnia and Herzegovina $v$ Serbia and Montenegro), Merits, Judgment, ICJ Reports 2007, p. 43, at 116, 121, 126, 186, 202, 207-8, 217 and 222, paras. 173, 186, 199, 344, 385, 398, 420, 431 (ten references to the ILC); Territorial and Maritime Dispute between Nicaragua and Honduras in the Caribbean Sea (Nicaragua v Honduras), Merits, Judgment, ICJ Reports 2007, p. 659, at 774, para. 280 (two references to the ILC); Ahmadou Sadio Diallo (Guinea v Democratic Republic of the Congo), Preliminary Objections, Judgment, ICJ Reports 2007, p. 582, at 599, 603, 606, 613, 615 and 616, paras. 39, 54, 64, 84, 91 and 93 (several references to the ILC); Maritime Delimitation in the Black Sea (Romania v Ukraine), Merits, Judgment, ICJ Reports 2009, p. 61, at 106-7, para. 134 (ILC); Pulp Mills on the River Uruguay (Argentina v Uruguay), Merits, Judgment (not yet published), at 77, para. 273 (ILC); Ahmadou Sadio Diallo (Guinea v Democratic Republic of the Congo), Merits, Judgment (not yet published), at 24, para. 66 (UN Human Rights Committee, general comment); Judgment No. 2867 of the Administrative Tribunal of the International Labour Organization Upon a Complaint Filed Against the International Fund for Agricultural Development, Advisory Opinion (not yet published), at 16, para. 39 (two references to the UN Human Rights Committee, general comments); Jurisdictional Immunities of the State (Germany v Italy; Greece intervening), Merits, Judgment (not yet published), at 24, 29, 36-7 and 50, paras. 56, 69, 89 and 137 (four references to the ILC). 


\subsection{Use of publicists can helpfully be segregated into several category.}

My review of the dataset indicates that use of publicists by the Court falls into one of several categories. This list will require refinement: there are, of course, many citations that do not fall neatly into only one or, in some cases, any categories.

Demonstrating widespread State practice. Where a publicist has conducted a thorough review of State practice and concluded that the threshold for a rule of customary international law has (or has not) been met, judges frequently rely upon those teachings, rather than directly citing primary evidence of State practice ${ }^{74}$ This practice is perfectly consistent with the scholars' characterization of doctrine as providing evidence of the existence of primary rules of law.

Interpreting a treaty provision. Judges also rely upon the authorized ${ }^{75}$ and unofficial ${ }^{76}$ commentaries of publicists on treaties, especially where such treaties were subject to extensive negotiation or have been the subject of considerable subsequent State practice or scholarly commentary. This practice is likewise consistent with the scholars' characterization of doctrine as providing evidence of the existence of primary rules of law.

74 In addition to Judge Dillard's reference to McDougal and Burke discussed supra note 60, see, e.g. Bosnian Genocide case, supra note 73, at 330, note 12 (Judge Tomka, Separate Opinion), in which Judge Tomka relies upon doctrine to show State practice concerning succession in the event of complete dismemberment of a State, citing A. Zimmermann, Staatennachfolge in völkerrechtliche Verträge: Zugleich ein Beitrag zu den Möglichkeiten und Grenzen völkerrechtlicher Kodifikation (Springer, 2000), at 860.

75 For example, both the separate opinion of Judge ad hoc Bula-Bula and the joint separate opinion of Judges Higgins, Kooijmans and Buergenthal in the Arrest Warrant case refer to the authorized commentary of Jean Pictet on the first Geneva Convention. Arrest Warrant of 11 April 2000 (Democratic Republic of Congo v Belgium), Merits, Judgment, ICJ Reports 2002, p. 3, at 71, paras. 31 (Judges Higgins, Kooijmans and Buergenthal, Separate Opinion), 122 and 123 (Judge Bula-Bula, Separate Opinion).

76 For example, Zimmermann, supra note 1, has been cited in individual opinions by Judge ad hoc Dugard (Certain Activities Carried Out by Nicaragua in the Border Area (Costa Rica $v$ Nicaragua), Provisional Measures, Order, (not yet published), at 2, para. 2 (Judge Dugard, Separate Opinion)), Judges Al-Khasawneh and Simma (Pulp Mills case, supra note 73, at 5, para. 14 (Judges Al-Khasawneh and Simma, Dissenting Opinion)), and Judge Bennouna (Pulp Mills on the River Uruguay (Argentina v Uruguay), Provisional Measures, Order, ICJ Reports 2006, p. 113, at 146, para. 13 (Judge Bennouna, Separate Opinion) and Territorial and Maritime Dispute (Nicaragua v Colombia), Preliminary Objections, Judgment, ICJ Reports 2007, p. 832, at 932 (Judge Bennouna, Dissenting Opinion)). 
Demonstrating a general principle of law. Individual opinions frequently cite the studies of one or more authors concerning State practice in foro domestico to establish a general principle of law under Article 38(1)(c) of the Statute 77 Likewise, judges cite publicists in support of a purported maxim of law ${ }^{78}$ Both practices are consistent with the consensus understanding of doctrine as an evidentiary source ${ }^{79}$

Explaining the practice of the Court itself. One of the most common uses of publicists is to describe the procedure of the ICJ. Shabtai Rosenne is the second most cited publicist (behind only the ILC), with 140 references in 75 different opinions, spanning 47 different phases or cases. Rosenne's research into such procedural matters as third-party intervention, the nature of a justiciable dispute, and provisional measures, has been cited in individual opinions for three decades.

Likewise, Sir Gerald Fitzmaurice, most commonly cited for issues concerning admissibility, the jurisdiction of the Court, and the scope and nature of party consent, ranks fifth among publicists, with 61 references in 46 different opinions. Fitzmaurice is frequently cited to describe the procedures and procedural limitations of the Court.

The invocation of doctrine in this realm is not surprising, as external primary sources, apart from its own broadly-worded Statute and Rules of Court, are not to be expected. However, this is one realm in which jurisprudence is capable of displacing doctrine; namely, once a Judgment is delivered concerning

77 See, e.g., Barcelona Traction, Light and Power Company, Limited (Belgium $v$ Spain), Second Phase, Judgment, ICJ Reports 1970, p. 3, at 70, para. 11 (Judge Fitzmaurice, Separate Opinion), where Judge Fitzmaurice cites surveys by W. E. Beckett and J. Mervyn Jones of American, Austrian, Belgian, Dutch, English, French, German, Italian, Norwegian, Swedish and Swiss law concerning the power of shareholders to bring a suit to protect their interests in the company.

78 See, e.g., Corfu Channel case, supra note 69, at 106, para. 34 (Judge Azevedo, Dissenting Opinion), in which Judge Azevedo cites Stelios Seferiades, (1930/IV) 34 Hague Recueil 177, at 439 , for the maxim, "[t]he greater the use of the [coastal] passage ... the more extensive become the infringements of the rights of the coastal States." Such use is consistent with the intent of Lord Phillimore, the co-author of Article 38(1)(c).

79 See Procés-Verbaux, supra note 5, at 335 ("Lord Phillimore explained that by 'general principles' he had intended to mean 'maxims of law'”). Schwarzenberger criticized over-reliance on maxims as one of the failings of the deductive method of legal inquiry. See Schwarzenberger, supra note 39, at 242-3 ("As has been so frequently the fate of natural law, so maxims, meant originally to be helpful devices for purposes of teaching and memorising, may be degraded into legal disguises of intrinsically political postulates. It is against this type of unholy mixture of law and politics that the doctrine of international law requires to be immunised"). 
intervention, future opinions can rely upon that Judgment, rather than underlying doctrine, for the legal standard 80

Providing general context for a specific point or case. ICJ judges frequently cite a publicist, without explanation, for the avowed purpose of providing context or discussion of a citation of a primary source. Examples are numerous, but one example will serve to illustrate the practice. In a 1999 Separate Opinion, Judge Weeramantry observed:

Bearing in mind that the object of a request for clarification, as stated in Factory at Chorzow is "to enable the Court to make quite clear the points which had been settled with binding force in a judgment", it seems to me that this object is fully satisfied by Nigeria's request ${ }^{81}$

While a simple citation to the Chorzow Factory judgment would have sufficed, Judge Weeramantry's footnote read:

Interpretation of Judgments Nos. 7 and 8 (Factory at Chorzow), Judgment No. 11, 1927, P.C.I.J., Series A, No. 13, p. 11. See also Manley O. Hudson, The Permanent Court of International Justice, 1972. Louis B. Sohn (ed.), p. $59{ }^{82}$

The doctrinal source adds nothing to the authority of the referenced rule, and in this sense can be viewed as intended merely to aid the persuasiveness of the citation by providing relevant context. In this sense, one might well wonder whether it is, in fact, an application of doctrine.

Directly demonstrate the existence of a rule of law. In his Individual Opinion in the Anglo-Norwegian Fisheries case ${ }^{83}$ Judge Alvarez concurred in the result of the Judgment, but presented distinct legal bases for the outcome. In particular, he

${ }^{80}$ See, e.g., Territorial and Maritime Dispute (Nicaragua v Colombia), Application by Costa Rica for Permission to Intervene, Judgment (not yet published), at 12-14, paras. 27-34 (citing the intervention judgments in the Land, Island and Maritime Dispute (1990) case and the Sovereignty over Pulau (2001) case for the legal standards surrounding permission to intervene.

81 Request for Interpretation of the Judgment of 11 June 1998 in the Case concerning the Land and Maritime Boundary between Cameroon and Nigeria (Cameroon v Nigeria), Preliminary Objections (Nigeria v Cameroon), Merits, Judgment, ICJ Reports 1999, p. 31, at 44 (Judge Weeramantry, Separate Opinion).

82 Ibid. at 44 , note 2.

${ }^{83}$ Fisheries case, supra note 43, at 145 et seq. (Judge Alvarez, Individual Opinion). 
conceded that acquisitive prescription of territory did not exist in international law, but argued that it "is recognized, in particular, in the case of the acquisition and the exercise of certain rights" ${ }^{84}$ In support of this recognition, he cited two sources: the "Declaration of the Great Principles of Modern International Law", which was, according to Alvarez "approved by three great associations devoted to the study of international law 85 (but not, significantly, authored by or adopted by States); and the 1928 Draft Rules for the Territorial Sea in Peacetime of the Institut de droit international. No evidence of custom or convention was presented. At best, Alvarez argued that the principles of modern international law generally "have their origin in the legal conscience of peoples" ${ }^{86}$ an oblique reference to general principles; however, no such argument was proferred in support of the Draft Rules.

Such usage finds support in the remarks of Lord Phillimore, who it will be recalled believed that doctrine was "universally recognised as a source of international law", ${ }^{87}$ but has largely been rejected by scholars ${ }^{88}$

Advocating for a change in the law. This is the most problematic of the categories, from the perspective of the Statute and from the perspective of the survey. Several judges-including Judge Alvarez in the early years of the Court and Judge Cançado Trindade in the present day-utilize their individual opinions to unabashedly urge a rethinking of public international law. Because their positions are by definition progressive, primary sources of law are lacking. They rely heavily, therefore, upon publicists. Indeed, Judge Cançado Trindade's entire Separate Opinion in the Request for Interpretation of the Judgment of 15 June 1962 in the Case Concerning the Temple of Preah Vihear ${ }^{89}$ which cites 28 different publicist sources in 32 substantive pages, can be seen as a comprehensive manifesto for the progressive development of international law to incorporate the temporal dimension of law ${ }^{90}$ and the human and cultural, rather than territorial, element of statehood ${ }^{11}$

Such a use of publicists is not consistent with the concept of teachings as a source of law, as it focuses on lex ferenda rather than lex lata. However, such use

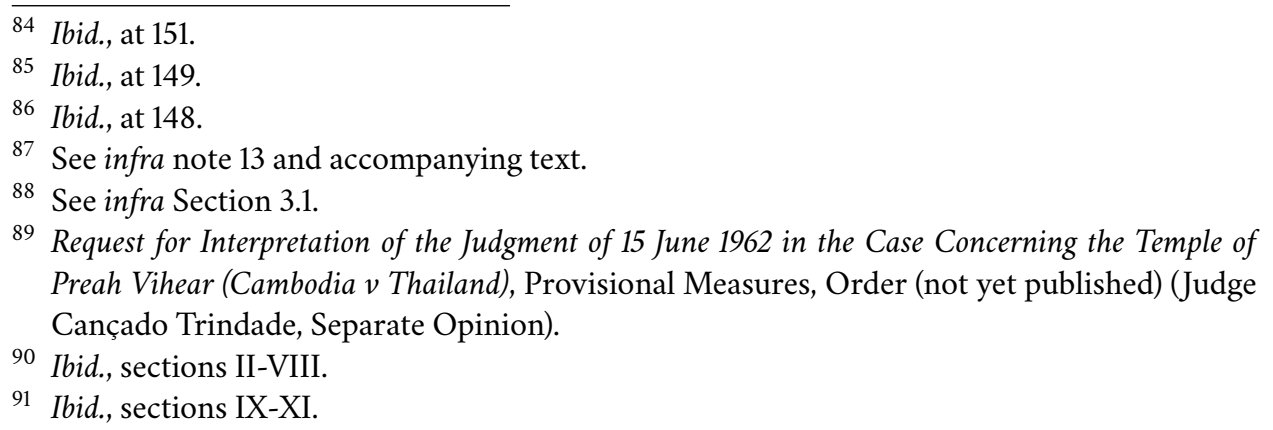


of doctrine de lege ferenda in support of an opinion which argues for progressive development is consistent with Shahabuddeen's view that one function of an individual opinion is to "clarify or restate the law in a way which proves to be helpful to its development" Spender's declaration in South West Africa, in which he set out four conclusions concerning the proper scope of individual opinions, and concluded that "there must exist a close link between individual opinions and the judgment of the Court" 93

\subsection{Generalists outpace specialists}

One clear observation from the data is that publicists who write across a broad range of topics - and, for that matter, abridgments-are cited much more often than specialists. Even setting aside his work as editor of Oppenheim's International Law, Sir Hersch Lauterpacht places third among publicists, with 98 references in 61 different opinions. He is cited for such varied topics as principles of treaty interpretation ${ }^{94}$ and immunities ${ }^{95}$ Oppenheim's itself places sixth among sources, with 54 mentions in 40 opinions.

By contrast, the highest-ranking 'specialists' are Joe Verhoeven (nearly exclusively cited for criminal procedure matters, including head-of-state immunity and genocide) with 24 references in just six opinions, and William A. Schabas, 19 of whose 20 citations occur in opinions in the Bosnian Genocide case.

This is not particularly surprising: neither the Court nor the publicists themselves control the docket of the Court. The Court simply has more opportunities to cite publicists who have written in a number of different areas; by contrast, a genocide scholar is likely only to be cited in cases concerning genocide.

\footnotetext{
92 Shahabuddeen, supra note 51, at 193.

93 South West Africa (Ethiopia v South Africa; Liberia v South Africa), Second Phase, Judgment, ICJ Reports 1966, p. 6, at 54-5, para. 22 (Judge Spender, Declaration).

94 See, e.g., Maritime Delimitation and Territorial Questions between Qatar and Bahrain (Qatar v Bahrain), Jurisdiction and Admissibility, Judgment, ICJ Reports 1995, p. 6, at 27 (Judge Schwebel, Dissenting Opinion); see also South West Africa Cases (Ethiopia v South Africa; Liberia v South Africa), Preliminary Objections, Judgment, ICJ Reports 1962, p. 319, at 227 (Judge Wellington Koo, Dissenting Opinion).

95 See, e.g., Arrest Warrant case, supra note 75, at 160-1, para. 35 (Judge ad hoc Van Den Wyngaert, Dissenting Opinion); see also Jurisdictional Immunities case, supra note 73, at 6, para. 17 (Judge Keith, Separate Opinion).
} 


\subsection{It is possible to identify the "most-favored publicists"}

Based upon a raw compilation of the number of citations, it is possible to make some preliminary observations about the most commonly cited publicists in the opinions of the Court. It is important, however, to also take into account the number of different opinions which cite a given publicist ${ }^{96}$ Because of the imprecision of my methodology thus far, I will refrain from attaching specific numbers to any author (other than those mentioned elsewhere), but the following tiers appear to describe the preferences of the Court:

Ubiquitous publicists. The following publicists are cited more than 80 times in more than 40 opinions.

1. The International Law Commission. See the discussion supra Section 5.2.

2. Shabtai Rosenne. In particular, the various editions of his The Law and Practice of the International Court of Justice ${ }^{97}$

3. Sir Hersch Lauterpacht. This excludes citations to Oppenheim's International Law under his editorship, which is treated separately.

4. L'Institut de droit international.

Commonly cited publicists. The following publicists are cited between 50 and 60 times, in over 30 opinions.

5. Sir Gerald Fitzmaurice.

6. Oppenheim's International Law ${ }^{98}$ in all of its editions.

7. Manley O. Hudson. Most popular among his works is the various editions of his book, The Permanent Court of International Justice ${ }^{99}$

8. Charles de Visscher. His most frequently cited work is Theory and Reality in Public International Law 100

\footnotetext{
96 For example, the scholarly writings of Judge Cançado Trindade are cited 62 times. All but one, however, were citations from the opinions of Judge Cançado Trindade himself.

97 Supra note 29.

98 Supra note 47.

99 Supra note 25.

${ }^{100}$ C. de Visscher, Theory and Reality in Public International Law (P. E. Corbett trans., 1968).
} 
Frequently cited publicists. The following writers are cited between 20 and 40 times, in 20 or more opinions.

6. Sir Ian Brownlie. Brownlie's textbook, Principles of Public International Law ${ }^{101}$ is his most frequently cited work.

7. Sir Humphrey Waldock. His work as Special Rapporteur at the International Law Commission and his time as editor of Brierly's The Law of Nations $\$$ are the most productive of citations.

8. Sir Robert Y. Jennings. Like Lauterpacht, this number excludes citations to Oppenheim's International Law on his watch.

9. Emerich de Vattel. Vattel places first in the rankings among members of the 'founding generation' of international law. His Le droit des gens ${ }^{103}$ is most popular with the Court.

Other cited publicists. The following writers are cited between 20 and 30 times, in between 10 and 20 opinions.

10. Julius Stone. In particular, his Legal System and Lawyers' Reasoning 104

11. James L. Brierly. In particular, his textbook, The Law of Nations. ${ }^{105}$

12. Georg Schwarzenberger. In particular, the volumes of his International Law as Applied by International Courts and Tribunals ${ }^{106}$

13. C. Wilfred Jenks. Roughly evenly divided between his The Common Law of Mankind ${ }^{107}$ and The Prospects of International Adjudication ${ }^{108}$

14. Sir Arnold McNair. Again setting aside his contributions to Oppenheim's, his The Law of Treaties $\sqrt{109}$ accounts for nearly all of his citations.

\footnotetext{
101 Supra note 34.

102 H. Waldock (ed), The Law of Nations (Oxford University Press, 1963).

${ }^{103}$ E. Vattel, Les droit des gens (1758), available in The Classics of International Law, J. B. Scott (ed) (Carnegie, 1916).

104 J. Stone, Legal System and Lawyers' Reasoning (Maitland, 1964).

${ }^{105}$ Supra note 102.

${ }^{106}$ Supra note 2.

107 C. Jenks, The Common Law of Mankind (Stevens, 1958).

${ }^{108}$ C. Jenks, The Prospects of International Adjudication (Stevens, 1964).

${ }^{109}$ A. McNair, The Law of Treaties (Clarendon Press, 1961).
} 
15. Eduardo Jiménez de Aréchaga.

16. Georges Scelle.

17. Philip C. Jessup.

18. Dionisio Anzilotti.

19. Roberto Ago.

20. Oscar Schachter.

Other publicists receiving a number of citations across several cases and/or authors are Joe Verhoeven, Nagendra Singh, William Schabas, Edvard Hambro, Grotius, the ICRC, the International Law Association, Hans Kelsen, Paul Reuter, D. P. O'Connell, Quincy Wright, Malcolm Shaw, Bin Cheng, Dame Rosalyn Higgins, and Mohammed Bedjaoui. At this stage, the distinctions between tiers become quite close, so a cutoff at this point is quite arbitrary.

\subsection{It remains difficult to identify 'most favored specialists'}

Although very tentative conclusions may be drawn from the raw number of citations to a given specialist, the numbers are so small that individual judge's preferences skew the data. For example, 13 of the 20 cites to Professor Schabas come from Judge ad hoc Kreca in two phases of the Bosnian Genocide case-five of the others come from Judge ad hoc Mahiou in the same case. Likewise, Judge Weeramantry contributed all but two of the references to the works of Burns Weston. While it is of course possible to statistically correct for such occurrences, the size of the dataset may preclude drawing meaningful conclusions from the corrected data.

\section{Conclusion: proposals for future research}

This discussion is preliminary. In a future paper, I intend to improve the methodologies to enable more principled conclusions concerning the Court's use of Article 38(1)(d) sources. In particular, I propose the following next steps in this study:

Second pass at the original documents. In order to minimize human error, the project will require a second, independent review of the source material. 
Critical evaluation of 'application' of a source. As noted above, the survey dataset at present is over-inclusive: there are numerous examples of law-related sources that are not, in fact, used as sources or evidences of a rule of law. (For example, sources in the final two categories described in Section 5.3 supra (general context and lex ferenda) are not, strictly speaking, intended by the authors as evidence of the law.

Defining the quantum of a 'citation'. Different authorities adopt different practices concerning citation. As a result, a single paragraph of an opinion may contain several pinpoint cites to the same source. Further complicating matters, an opinion may rely upon the same source for multiple propositions of law. For this survey, I have made an ad hoc determination on a case-by-case basis as to whether any two citations are unique. In the next iteration, I will need to adopt and apply a regular standard.

A later stage of this research will involve analysis of the use of publicists by counsel for parties before the Court, in oral and written submissions, to identify similarities and differences in the attitudes of bench and bar, and to determine what effect, if any, these differences have on the practice of the Court. 